\title{
Antiplasmodial Potential and Phytochemical Evaluation of Aqueous Root Extract of a Nigerian Medicinal Apocynaceae Plant
}

\author{
Chidiebere A. Otuu ${ }^{1 *}$, Rose N. N. Obiezue ${ }^{1}$, Chris I. Okoye ${ }^{1}$, Innocent C. J. Omalu ${ }^{2}$, Innocent C. Ekuma ${ }^{3}$, Ada Q. A. Otuu ${ }^{4}, 5$, \\ Samuel S.Eke ${ }^{6}$, Emmanuel. O. Udeh ${ }^{7}$, Suleiman C. Hassan ${ }^{8}$, Hadijah U. Yamman ${ }^{2}$ and Fabian C. Okafor ${ }^{1}$ \\ ${ }^{l}$ Parasitology and Public Health Unit, Department of Zoology and Environmental Biology, University of Nigeria, Nsukka, Enugu \\ State, Nigeria \\ ${ }^{2}$ Department of Animal Biology, Federal University of Technology, Minna, Niger State, Nigeria. \\ ${ }^{3}$ Department of Biomedical Engineering, Alex Ekwueme Federal Teaching Hospital, Abakaliki, Ebonyi State, Nigeria. \\ ${ }^{4}$ Department of Public Health, West African Postgraduate College of Pharmacists, Yaba, Lagos State. \\ ${ }^{5}$ Department of Pharmacy, Alex Ekwueme Federal University Teaching Hospital Abakaliki, Ebonyi State, Nigeria. \\ ${ }^{6}$ Department of Biology, Air Force Institute of Technology, Kaduna, Kaduna State, Nigeria. \\ ${ }^{7}$ Centre for Integrated Health Programs, Wuse 2, Federal Capital Territory, Abuja, Nigeria. \\ ${ }^{8}$ Department of Zoology, Nasarawa State University, Keffi, Nigeria.
}

* Corresponding author

\begin{abstract}
The increasing resistance of the malaria parasite to currently used antimalarial medicines has intensified the research for new novel antimalarial drug leads from natural sources. This study was carried out to evaluate the antiplasmodial potential, phytochemical composition and toxicity status of aqueous root extract of Alstoniaboonei (Apocynaceae), a medicinal plant used in treating malariain Nigeria and other African countries. The extract showed substantial dose dependent antiplasmodial activity as indicated by the, suppressive $(40.18 \%, 55.72 \%$ and $61.55 \%$ for 100,200 and 400 mgkg $^{-1}$ body weights), prophylactic $(51.39 \%, 65.27 \%$ and $68.35 \%$ for 100,200 and $400 \mathrm{mgkg}^{-1}$ body weights), and curative $\mathbf{( 4 8 . 6 3 \%}, 59.59 \%$ and $60.88 \%$ for 100,200 and $400 \mathrm{mgkg}^{-1}$ body weights) effects on Plasmodium berghei infected albino mice. The antiplasmodial activity was significantly different compared to the negative control at $P<0.05$. Chemical compounds obtained from the phytochemical evaluation of the extract include tannins, flavonoids, steroids, phenols, alkaloids, saponins, glycosides and terpenoids. There were no observed signs of toxicity in all the oral doses tested on albino mice. It was concluded that the extract contains important active antimalarial compounds that are not toxic and should be further investigated for antimalarial drug development.
\end{abstract}

Keywords: Antiplasmodial, Phytochemical, Alstonia boonei, Plasmodium berghei, Suppressive, Prophylactic, Curative.

\section{INTRODUCTION}

$\mathrm{T}$ he utilization of plants against diseases is believed to be derived from the chemicals available in them. Many modern medicines are derived from plants that have been used by traditional medical practitioners. Alstoniaboonei is one of the many medicinal plants found in Nigeria and other African countries. The plant parts have been traditionally used to treat various ailments including malaria $(1,2,3,4,5)$.
Various chemical constituents have been isolated from $A$. boonei, and some of them have been found to possess a range of pharmacological activities including antimalarial activities $(6,7,8)$.

\section{MATERIALS AND METHODS}

\subsection{Collection and Authentication of Plant Material}

Alstoniaboonei root parts were collected from Obollo A for town in Enugu State, Nigeria and identified and authenticated by a botanist at the Department of Plant Science and Biotechnology, University of Nigeria Nsukka, Enugu State, Nigeria. The specimen was documented and assigned voucher number 7603.

\subsection{Experimental Animals}

Animal tests were carried out according to the National Institute of health (NIH) 1996guide for the care and use of laboratory animals, NIH publication (volume 25, number 28), revised 1996(move to references and give number of reference). Approval was obtained for all animal experiments from the University of Nigeria Ethical Committee on the use of laboratory animals for research with approval number UNN-ERC/Z/9875 - 7/5/18

Inbred Swiss albino mice of both sexes weighing between 20 and $22 \mathrm{~g}$ were used for this study. The animals were obtained from the animal house of the Nigerian Institute of Medical Research, Yaba, Lagos, Nigeria. They were acclimatized for seven days and fed mice feed and tap water ad libitum.

\subsection{Parasite Strain for the Study}

Chloroquine sensitive Plasmodium berghei NK65 strain was used for this study. It was obtained from the Nigerian Institute 
of Medical Research, Yaba, Lagos, Nigeria and maintained in mice by serial passage.

\subsection{Preparation of Plant Materials}

The root parts of A.boonei earlier collected were cut into small pieces, washed and air dried for two weeks under room temperature. The dry samples were then ground into powder with a mechanical blender.

\subsection{Extraction Method}

$500 \mathrm{~g}$ of the ground fine powder obtained was percolated in $1600 \mathrm{~mL}$ of water for $72 \mathrm{~h}$ after which it was filtered. This was followed by evaporating the filtrate collected to dryness using a temperature-regulated water bath pre-set at $40^{\circ} \mathrm{C}$ to yield the extract concentrate which was stored in the refrigerator at $4^{\circ} \mathrm{C}$ before use.

\subsection{Phytochemical Test of the Extract}

Standard chemical tests were carried out on the extract to determine the presence of phytochemical compounds in the extract following the methods described by Roghini and Vijayalakshmi 2018 (9). Each test was qualitatively expresses as negative (-) or positive (+): The intensity of the characteristic colour was expressed as (+), (++) or (+++).

\subsection{Acute Toxicity Test of the Extract}

The acute toxicity test of the aqueousroot extract of A. boonei was evaluated using the methods described by Lorke 1983 (10). The vehicle for the extract administration to experimental mice was corn oil. A 4 hour fast period was done after which 15 mice were divided into groups of three. The extract doses were calculated in reference to the body weight of the mice. Each mouse was then treated with a single oral dose of the extract. The administered doses were 5, 50, 300,1200 and $1500 \mathrm{mgkg}^{-1}$ body weight. The animals were observed for three hours after dosing for signs of toxicity. A single high oral dose of $5000 \mathrm{mgkg}^{-1}$ body weight was then administered to a group of three male and three female mice while the control group was administered with the vehicle. The animals were given food one hour after the administration of the extract and vehicle for the control group. The animals were observed 30 minutes after dosing followed by hourly observation for a period of 8 hours and then once a day for the next 13 days. Daily observations including physical change, signs of illness and mortality were recorded and surviving mice were weighed.

\subsection{Antimalarial Tests of the Extract}

\subsubsection{Test for suppressive activity}

The suppressive activity of the extract was evaluated in early Plasmodium berghei infection in white albino mice using the methods described byPeters 1967 (11). Fifteen mice were randomly divided into five groups of three mice each. On the first day (D0), the mice were each infected with $10^{7}$ Plasmodiumberghei. Three hours later the infected mice were each treated orally with $10 \mathrm{mLkg}^{-1}$ body weight of the extract or $10 \mathrm{mgkg}^{-1}$ body weight of chloroquine. Group 1 , the negative control, was given $5 \mathrm{mLkg}^{-1}$ normal saline. Group 2, the positive control, was treated with $10 \mathrm{mgkg}^{-1}$ chloroquine. Groups 3 to 5 were treated with the extract.

The extract was administered orally at a dose of 100, 200 and $400 \mathrm{mg}$ extract $\mathrm{kg}^{-1}$. Treatment was carried out for four consecutive days (D0 - D3). The body weight of each mouse was measured on the first day (D0) and on the fifth day (D4). The body temperature was also taken before infection and three hours after infection (on D0) and then monitored daily to the fifth day (D4).

On the fifth day (D4), thin blood film was prepared from the tail blood of the mice. The thin blood film was fixed in methanol and stained with Giemsa to reveal parasitized erythrocytes. Parasitaemia was determined using light microscopy with 100X objective lens.

\subsubsection{Test for prophylactic activity}

The prophylactic activity of the extract was determined using the methods of Peters 1965 (12). Another set of fifteen mice were randomly divided into five groups of three mice each. Group 1, the negative control, was given $5 \mathrm{mLkg}^{-1}$ normal saline. Group 2, the positive control, was treated with $10 \mathrm{mgkg}^{-1}$ chloroquine. Groups 3 to 5 were treated with the extract. The extract was administered orally at a dose of 100 , 200 and $400 \mathrm{mg}$ extract $\mathrm{kg}^{-1}$. Treatment was carried out for three consecutive days (D0 - D2). On the fourth day (D3) the mice were inoculated with $10^{7} \mathrm{P}$. berghei infected red blood cells. After 72 hours the level of parasitaemia was then determined using microscopy.

\subsubsection{Test for curative activity}

The curative activity of the extract on established infections of Plasmodiumberghei on mice was assessed using the method earlier described by Ryley and Peters (13). Another set of fifteen mice were infected with $10^{7} P$. berghei by intra peritoneal injection on the first day (D0). 72 hours later the mice were randomly divided into five groups of three mice each. Three groups of the mice (Groups 1 to 3 ) were treated orally with a dose of 100,200 and $400 \mathrm{mg} \mathrm{kg}^{-1}$ body weight of the extract. The negative control group (Group 4) was given 5 $\mathrm{mLkg}^{-1}$ normal saline while the positive control group (Group 5) was treated with $10 \mathrm{mgkg}^{-1}$ chloroquine.

The treatments with the extract and drug was done once daily for five days. Parasitaemia levels was checked each day by preparing Giemsa-stained thin smears from blood samples collected from the tail of the mice and examined under the microscope. The body weight and temperature were taken before infection (D0) and from the fourth day (D3) to the eight day (D7). 


\section{RESULTS}

The result of the qualitative phyto chemical analysis showed that tannin and phenol showed highest intensity of the characteristic colou rand thus was the most abundant in the extract followed by flavonoids, steroids, alkaloid, saponin, glycoside and terpenoid showing the same colour intensities. The results of the qualitative phytochemical analysis of the extractis shown in Tables 1 . In the quantitative analysis, phenol was the highest followed by tannin, flavonoid, terpenoid, glycoside, alkaloid, steroid and saponin. The result of the quantitative phytochemical analysis is shown in Table 2 and Figure 1.

Table1: Results of the qualitative phytochemical analysis of A.booneiaqueous

\begin{tabular}{|c|c|c|c|c|c|c|c|c|}
\hline $\begin{array}{c}\text { Extra } \\
\text { ct }\end{array}$ & $\begin{array}{c}\text { Tan } \\
\text { nin }\end{array}$ & $\begin{array}{c}\text { Flavo } \\
\text { noid }\end{array}$ & $\begin{array}{c}\text { Ster } \\
\text { oid }\end{array}$ & $\begin{array}{c}\text { Phe } \\
\text { nol }\end{array}$ & $\begin{array}{c}\text { Alkal } \\
\text { oid }\end{array}$ & $\begin{array}{c}\text { Sapo } \\
\text { nin }\end{array}$ & $\begin{array}{c}\text { Glyco } \\
\text { side }\end{array}$ & $\begin{array}{c}\text { Terpe } \\
\text { noid }\end{array}$ \\
\hline $\begin{array}{c}\text { Root } \\
\text { aque } \\
\text { ous }\end{array}$ & ++ & + & + & ++ & + & + & + & + \\
\hline
\end{tabular}

Legend: + = Low; ++ = Moderate; +++ = High.

Table2: Results of the quantitative phytochemical analysis of A.boonei ethanolic stem bark extract

\begin{tabular}{|c|c|c|c|c|c|c|c|c|}
\hline $\begin{array}{c}\text { Compo } \\
\text { und }\end{array}$ & $\begin{array}{c}\text { Tan } \\
\text { nin }\end{array}$ & $\begin{array}{c}\text { Flavo } \\
\text { noid }\end{array}$ & $\begin{array}{c}\text { Ste } \\
\text { roi } \\
\text { d }\end{array}$ & $\begin{array}{c}\text { Phen } \\
\text { ol }\end{array}$ & $\begin{array}{c}\text { Alka } \\
\text { loid }\end{array}$ & $\begin{array}{c}\text { Sa } \\
\text { po } \\
\text { nin }\end{array}$ & $\begin{array}{c}\text { Glyco } \\
\text { side }\end{array}$ & $\begin{array}{c}\text { Terpe } \\
\text { noid }\end{array}$ \\
\hline $\begin{array}{c}\text { Compo } \\
\text { sition } \\
(\mathrm{Mg} / 10 \\
0 \mathrm{~g})\end{array}$ & $\begin{array}{c}302 \\
.21\end{array}$ & $\begin{array}{c}179.3 \\
7\end{array}$ & $\begin{array}{c}2.2 \\
64\end{array}$ & $\begin{array}{c}638 . \\
931\end{array}$ & $\begin{array}{c}94.5 \\
17\end{array}$ & $\begin{array}{c}0.4 \\
27\end{array}$ & $\begin{array}{c}120.3 \\
75\end{array}$ & $\begin{array}{c}143.64 \\
9\end{array}$ \\
\hline
\end{tabular}

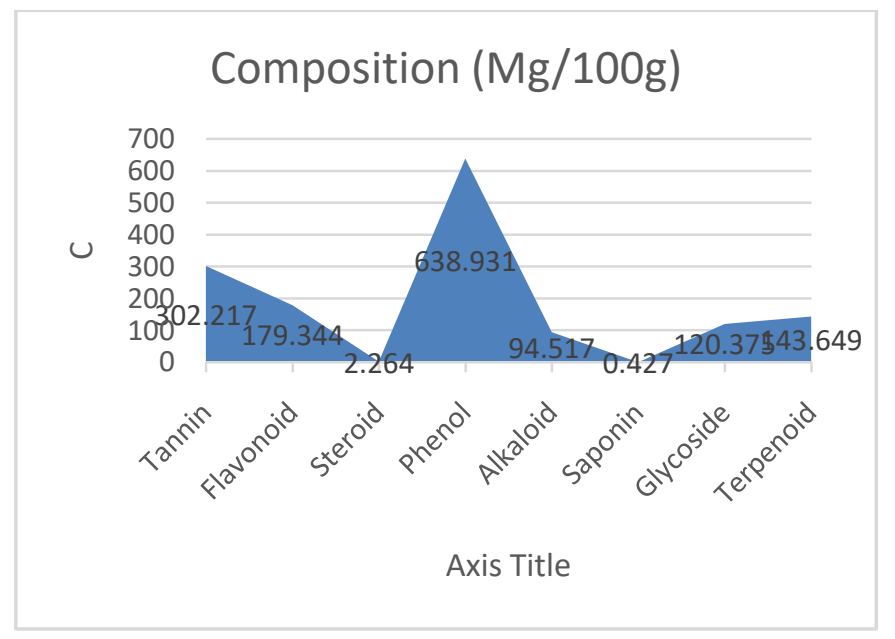

Figure 1: Results of the quantitative phytochemical analysis of A.boonei aqueous root extract

\section{Acute Toxicity Studies}

The LD50 of aqueous root extract of A.boonei was $5000 \mathrm{mg} / \mathrm{kg}$. The observed signs of toxicity in mice given $5000 \mathrm{mg} / \mathrm{kg}$ and above include drowsiness, weakness, licking of paws and reduction in activity. No mortality was observed in mice after oral administration of the doses of aqueous root extractof A. boonei up to $5000 \mathrm{mg} / \mathrm{kg}$ indicating that the extract is not toxic with oral LD50 greater than $5000 \mathrm{mg} / \mathrm{kg}$.

\section{Antimalarial tests}

The suppressive test of aqueous root extract of A. boonei revealed a significant suppression, at $\mathrm{P}<0.05$, on the fourth day of the test by the extract. The suppressive activity was dose dependent with a suppression of $40.18 \%, 55.72 \%$ and $61.55 \%$ respectively, as compared to the positive control, chloroquine, with a chemo suppression of $96.88 \%$ which was higher than the chemo suppression of the extracts. The results of the suppressive effect of the extract are shown in Table 3 and Figure 2 below.

Table 3: Suppressive effect of aqueousroot extract of A.booneiand chloroquine in mice infected withPlasmodium berghei

\begin{tabular}{|c|c|}
\hline Treatments & $\begin{array}{c}\text { Suppression } \\
(\%)\end{array}$ \\
\hline Distilled water $5 \mathrm{mlkg}^{-1}$ & 0.00 \\
\hline Extract $100 \mathrm{mkg}^{-1}$ & 40.18 \\
\hline Extract $200 \mathrm{mgkg}^{-1}$ & 55.72 \\
\hline Extract $400 \mathrm{mgkg}^{-1}$ & 61.55 \\
\hline Chloroquine $5 \mathrm{mgkg}^{-1}$ & 96.88 \\
\hline
\end{tabular}

Significantly different from the control at $\mathrm{P}<0.05$

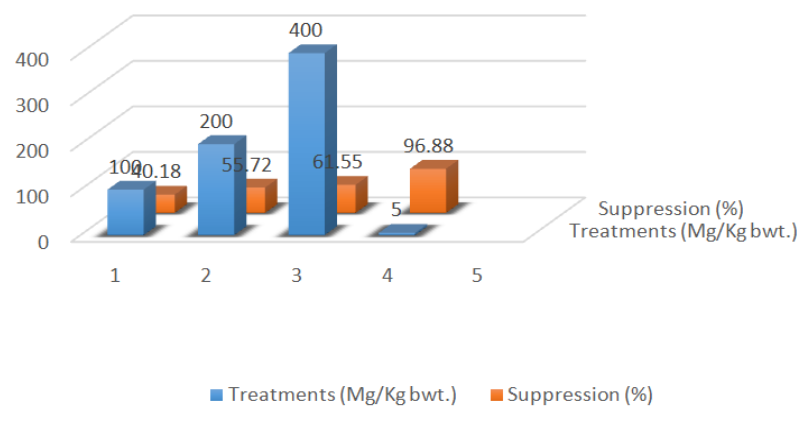

Figure 2: Suppressive effect of aqueousroot extract of A.boonei and chloroquine in mice infected with Plasmodium berghei

The prophylactic test of the aqueous root extract of A. boonei produced a significant dose dependent reduction, at $\mathrm{P}<0.05$, in parasitaemia levels of $51.39 \%, 65.27 \%$ and $68.35 \%$ while $5 \mathrm{mg}$ chloroquine $\mathrm{kg}^{-1}$ body weight produced $97.95 \%$ reduction in levels of parasitaemia. The significant reduction in parasitaemia by the extract indicates that the extracts possess schizonticidal activity in blood. The results of the prophylactic effect of the extract are shown in Table 4 and Figure 3 below.

Table 4: Prophylactic effect of aqueousroot extract of A.boonei and chloroquine in mice infected with Plasmodium berghei

\begin{tabular}{|c|c|}
\hline Treatments & Suppression (\%) \\
\hline Distilled water $5 \mathrm{mlkg}^{-1}$ & 0.00 \\
\hline Extract $100 \mathrm{mgkg}^{-1}$ & 51.39 \\
\hline Extract $200 \mathrm{mgkg}^{-1}$ & 65.27 \\
\hline Extract $400 \mathrm{mgkg}^{-1}$ & 68.35 \\
\hline Chloroquine $5 \mathrm{mgkg}^{-1}$ & 97.95 \\
\hline
\end{tabular}

Significantly different from the control at $\mathrm{P}<0.05$ 


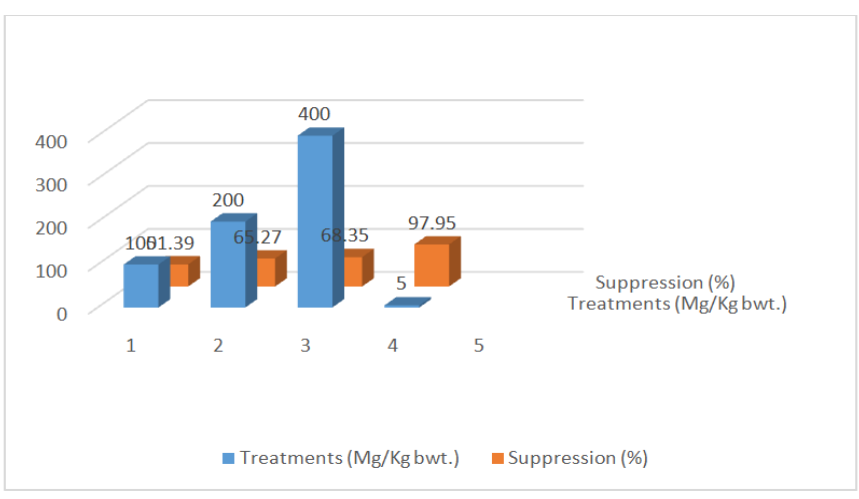

Figure 3: Prophylactic effect of aqueous root extract of A.boonei and chloroquine in mice infected with Plasmodium berghei

In the curative test of the aqueous root extract $A$. boonei, it was observed that the extract produced a dose dependent reduction in the levels of parasitaemia in the groups treated with the extracts. This result was also observed in the positive control group which were treated with chloroquine. On the seventh day of the curative test it was found that for the 100 , 200 and $400 \mathrm{mg} / \mathrm{kg} /$ day of the extract, the negative control group indicated an average percentage suppression of parasitaemia of $48.63 \%, 59.59 \%$ and $60.88 \%$ respectively while $5 \mathrm{mg}$ of chloroquine $\mathrm{kg}^{-1}$ body weight produced a reduction in parasitaemia of $95.74 \%$. The results of the curative effect of the extract are shown in Table 5 and Figure 3 below.

Table 5: Curative effect of aqueousroot extract of A.boonei and chloroquine in mice infected with Plasmodium berghei

\begin{tabular}{|c|c|}
\hline Treatments & Suppression (\%) \\
\hline Distilled water $5 \mathrm{mlkg}^{-1}$ & 0.00 \\
\hline Extract $100 \mathrm{mgkg}^{-1}$ & 48.63 \\
\hline Extract $200 \mathrm{mgkg}^{-1}$ & 59.59 \\
\hline Extract $400 \mathrm{mgkg}^{-1}$ & 60.88 \\
\hline Chloroquine $5 \mathrm{mgkg}^{-1}$ & 95.74 \\
\hline
\end{tabular}

Significantly different from the control at $\mathrm{P}<0.05$

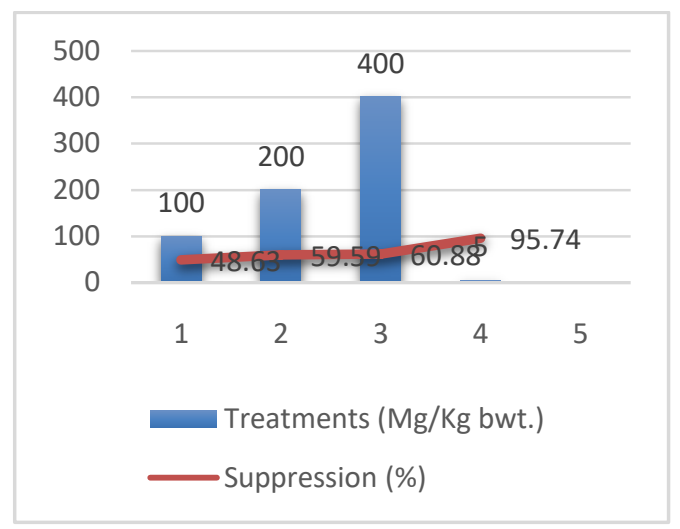

Figure 4: Curative effect of aqueous root extract of A.boonei and chloroquine in mice infected with Plasmodium berghei

\section{DISCUSSION AND CONCLUSION}

From the results of the phytochemical analysis, the rootaqueous extract of A.booneiwas found to contain important compounds including tannins, flavonoids, steroids, phenols, alkaloids, saponins, glycosides and terpenoids. These phytochemical compounds present in the plant have been reported by other studies to possess antimalarial activities $(14,15,16,17,18,19,20,21,22,23)$.

Fromthe acute toxicity test of this study, no mortality was recorded in all the doses used for the acute toxicity test which indicates that the extract is not toxic. The result of the toxicity test is similar to that reported in other studies $(2,3,4,16)$.

The suppressive test of the rootaqueous extract revealed a significant suppression on the fourth day of the test. The suppressive activity was dose dependent. The prophylactic test of the aqueous root extract produced a significant dose dependent reduction in parasitaemia levels which is an indication that the extract exerts schizonticidal activity in blood. The curative test of the aqueous root extract also produced a dose dependent reduction in the levels of parasitaemia in the groups treated with the extract. The results of the antiplasmodial tests are similar to the results recorded in other studies $(5,24,25,26,27)$.

The results from this study revealed that the aqueous root extract of Alstonia booneiconta in phytochemical compounds which are not toxic and exhibited significant antiplasmodial potential and thus should be further studied for antimalarial drug development.

\section{AUTHOR'S CONTRIBUTIONS}

This work was carried out in collaboration among all authors. Authors CAO, FCO, RNNO and CIO designed the study and managed the analyses of the study. Authors ICJO, SSE, ICE and EOU performed the statistical analysis, wrote the protocol and the first draft of the manuscript. Authors SCH, AQAO and HUY managed the literature searches. All authors read and approved the final manuscript.

\section{COMPETING INTERESTS}

The authors declare that no competing interests exist among them.

\section{REFERENCES}

[1] Ojewele, J. A. O. (1984). Studies on the Pharmacology of echitamine, an alkaloid from the stem bark of Alstoniaboonei $\mathrm{L}$. (Apocynaceae). International Journal of Crude Drug Research, 22(3), 121-143.

[2] Asuzu, U. and Anaga, A. O. (1991). Pharmacological Screening of the aqueous extract of Alstoniaboonei bark. Fitoterapia, 63(5), 411-417.

[3] Alli, L. A., Adesokan, A. A., Salawu, O. A., Akanyi, M. A. and Tyani, A. Y. (2011). Anti-plasmodial activity of aqueous root extract of Acacianilotica. African Journal of Biochemical Research, 5(7), 214-219.

[4] Ebiloma, G., Amlabu, E., Atanu, F. O., Amlabu, W. and Rhoda, O. A. (2012). Effect of the Aqueous Extracts of Alstoniaboonei on the Haematological Profiles of Mice Experimentally Infected with 
the Chloroquine-Sensitive Strain of Plasmodium berghei NK-65. Hematologia, 1(1), 11-18.

[5] Idowu, O. A., Soniran, O. T., Ajana, O. and Aworinde, D. O. (2010). Ethnobotanical Survey of Antimalarial oil plants used in Ogun State Southwest, Nigeria. African Journal of Pharmacy and Pharmacology, 4, 55-60.

[6] Babatunde, O. (2017). GC-MS analysis of leaf, stem-bark and root extracts of Alstoniaboonei. African Journal of Pharmacy and Pharmacology, 12(46), 577-581.

[7] Kumar, P., Chandra, S. M., Joel, J., Lipin, D. M. S., Arun, K. T. V. and Thankamani, V. (2011). Ethnobotanical and Pharmacological study of Alstonia (Apocynaceae). A Review. Journal of Pharmaceutical Sciences and Research, 3(8), 13941403 .

[8] Madhiri, R. and Vijayalakshini, G. (2018). A Review of Phytochemical Composition and Pharmacological Aspects of the Genus Alstonia. Pharma Tutor, 6(1), 50-55.

[9] Roghini, R. and Vijayalakshmi, K. (2018). Phytochemical Screening, Quantitative Analysis of Flavonoid and Minerals in Ethanolic Extract of Citrus Paradisi. Journal of Pharmaceutical Sciences and Research, 9(11), 4859-4864.

[10] Lorke, D. (1983). A new approach to acute toxicity testing. Archives of Toxicology,54, 275-287.

[11] Peters, W. (1967). Rational methods in the search for antimalarial drugs. Transactions of the Royal Society of Tropical Medicine and Hygiene, 61, 400-410.

[12] Peters, W. (1965). Drug resistance in Plasmodium berghei. Vincke and Lips, 1948; 1. Chloroquine resistance. Experimental Parasitology, 17, 80-89.

[13] Ryley, J. F. and Peters,W. (1970). The antimalarial activity of some quinolone esters. Ann. Trop. Med. Parasitol, 84, 209-222.

[14] Opoku, F. and Akoto, O. (2015). Antimicrobial and phytochemical properties of Alstoniaboonei extracts. Organic Chemistry Current Research, 4, 137.

[15] Akinmoladun, A. C., Ibukum, E. O., Afor, E., Akinrinlola, B. L., Onibon, T. R., Akinboye, A. O., Obuotor, E. M. and Farombi, E. O. (2007). Chemical constituents and antioxidant activity of Alstoniaboonei,African Journal of Biotechnology, 6(10), 11971201.

[16] Akbar, S., Hanif, U., Ali, J. and Ishtiaq, S. (2014). Pharmacognostic studies of stem, roots, and leaves of MalivaparvifloraL.Asian Pacific Journal of Tropical Medicine, 4(5), 410-415.
[17] Ayoola, G. A., Folawewo, A. D., Adesegun, S. A., Abioro, O. O., Adepoju-Bello, A. A. and Coker, H. A. B. (2008). Phytochemical and antioxidant screening of some plants of Apocynaceae from South West Nigeria. AfricanJournalofPlantScience, 2(9), 124-128.

[18] Edoga, H. O., Okwu, D. E. and Mbaebie, B. O. (2005). Phytochemical Constituents of some Nigerian Medicinal Plants. African Journal of Biotechnology, 4(7), 685-688.

[19] Elisabetsky, E. and Costa-Campus, L. (2006). The alkaloid alstonine: a review of its pharmacological properties. Evidence Based Complementary and Alternative Medicine, 3(1), 39-48.

[20] Gbadamosi, I. T., Moody, J. O. and Lawal, A. M. (2011). Phytochemical screening and proximate analysis of eight ethnobotanicals used as antimalarial remedies in Ibadan, Nigeria. Journal of Applied Biosciences, 44, 2967-2971.

[21] Gosse, B. K. and Bryson, T. A. (1999). Study of triterpenoids from Alstoniaboonei. Societ'e Duest - Africaine de Chimie, 5(8), 123128.

[22] Kumar, P., Chandra, S. M., Joel, J., Lipin, D. M. S., Arun, K. T. V. and Thankamani, V. (2011). Ethnobotanical and Pharmacological study of Alstonia (Apocynaceae). A Review. Journal of Pharmaceutical Sciences and Research, 3(8), 13941403.

[23] Madhiri, R. and Vijayalakshini, G. (2018). A Review of Phytochemical Composition and Pharmacological Aspects of the Genus Alstonia. Pharma Tutor, 6(1), 50-55.

[24] Tarkang, P. A., Okalebo, F. A., Ayong, L. S., Agbor, A. G. and Guntai, A. N. (2014). Anti-malarial activity of a polyherbal product (Nefang) during early and established Plasmodium infection in rodent models. Malaria Journal 2014, 13, 456.

[25] Obdoni, B. O. and Ochuko, P. O. (2001). Phytochemical Studies and Comparative efficacy of the crude extracts of some Homostatic plants in Edo and Delta States of Nigeria. Global Journal of Pure and Applied Sciences, 8b, 203-208.

[26] Bankole, A. E., Adekunle, A. A., Sowemimo, A. A., Umebese., C. E., Abiodun, O. and Gbotosho, G. O. (2016). Phytochemical screening and in vivo antimalarial activity of extracts from three medicinal plants used in malaria treatment in Nigeria. Parasitology Research, 115, 299-305.

[27] Bekono, B. D., Ntie-Kang, F., Onguene, P. A., Lifongo, L. L., Sippl, W., Foster, K. and Owono, L. C. O. (2020). The potential of anti-malaria compounds derived from African medicinal plants: a review of pharmacological evaluations from 2013 to 2019. Malaria Journal, 19, 183 